УДК 159.942

DOI https://doi.org/10.26661/2310-4368/2021-4-4

\title{
ОСОБИСТІСНА ГОТОВНІСТЬ ПЕРСОНАЛУ ОСВІТНІХ ОРГАНІЗАЦІЙ ДО КОНСТРУКТИВНОГО РОЗВ'ЯЗАННЯ КОНФЛІКТІВ ЯК ЧИННИК СУБ'ЄКТИВНОГО БЛАГОПОЛУЧЧЯ
}

\author{
Горова О. О. \\ доктор психологічних наук, дочент, \\ професор кафедри психології управління \\ ДВНЗ «Університет менеджменту освіти» \\ Начіональної академії педагогічних наук України» \\ вул. Січових стрільиів, 52-А, Київ, Україна \\ orcid.org/0000-0001-9005-9089 \\ gorovaya.111@gmail.com
}

\begin{abstract}
Ключові слова: особистісна готовність, персонал освітніх організацій, конструктивне розв'язання конфліктів, суб' 'ктивне благополуччя.
\end{abstract}

У статті представлено результати дослідження проблеми особистісної готовності персоналу освітніх організацій до конструктивного розв'язання конфліктів для досягнення ними суб'єктивного благополуччя. Розглянуто сутність дефініцій терміна «конфлікт» 3 погляду прихильників різних наукових підходів (психодинамічного, мотиваційного, ситуаційного, організаційного, особистісного, аналітичного й інших) - «готовність персоналу освітніх організацій до розв’ язання конфліктів», «суб'єктивне благополуччя». Висвітлено зміст готовності персоналу освітніх організацій до конструктивного розв'язання конфліктів, що передбачає вміння діагностувати ймовірність появи конфлікту, прогнозувати особливості його розвитку, запобігати, взаємодіяти в ситуації конфлікту, виходити із проблемних ситуацій тощо.

Вибір стратегії розв'язання конфлікту залежить від індивідуальних, сімейних та суспільних переконань, цінностей, досвіду, культури тощо. Здатність персоналу освітніх організацій контролювати із плином часу цілу низку чинників, як конструктивних, так і небажаних (стійкість, самореалізація, соціальна емоційна компетентність, особисті реакції на діяльність в освітній організації (виснаження, втома, стрес тощо)) в умовах конфліктної ситуації, є важливим чинником суб'єктивного благополуччя i передбачає опанування вмінь вибирати конструктивну позицію в освітній діяльності в момент розгортання конфлікту, прагнення дотримуватися настанов і правил діалогічного спілкування, уміння активно діяти на всіх етапах управління конфліктною ситуацією. Обгрунтовано, що суб'єктивно благополучний персонал освітніх організацій здатний не лише конструктивно розв' язувати різні конфлікти, a i сформувати в молоді загальнолюдські, національні, громадянські, сімейні й особистісні цінності. 


\title{
PERSONAL READINESS OF THE STAFF OF EDUCATIONAL ORGANISATIONS FOR CONSTRUCTIVE RESOLUTION OF CONFLICTS AS A FACTOR OF SUBJECTIVE WELL-BEING
}

\author{
Gorova O. $\mathbf{O}$. \\ Doctor of Psychological Sciences, Associate Professor, \\ Professor at the Department of Management Psychology \\ University of Educational Management of National Academy of Educational Sciences of Ukraine \\ Sichovykh Striltsiv str., 52-A, Kyiv, Ukraine \\ orcid.org/0000-0001-9005-9089 \\ gorovaya.111@gmail.com
}

\begin{abstract}
Key words: personal readiness, staff of educational organisations, constructive conflict resolution, subjective well-being.
\end{abstract}

\begin{abstract}
The article presents the results of a study of the problem of personal readiness of the staff of educational organisations to constructively resolve conflicts to achieve their subjective well-being.

The essence of the definitions of "conflict" from the point of view of scientists of different scientific approaches (psychodynamic, motivational, situational, organisational, personal, analytical, etc.), "readiness of the staff of educational organisations to resolve conflicts", "subjective well-being" are considered. The content of readiness of the staff of educational organisations to constructively resolve conflicts is covered, which includes the ability to diagnose the probability of conflict, predict the peculiarities of its development, prevent, interact in conflict situations, solve problem situations and more.

The ability of the staff of educational organisations to control over time several factors, both constructive and undesirable (stability, self-realisation, socialemotional competence), personal reactions to activities in an educational organisation (exhaustion, fatigue, stress, etc.) in conflict situations, is an important factor of subjective well-being and provides for the mastery of the skills to take a constructive position in educational activities at the time of the deployment of the conflict, the desire to adhere to the attitudes and rules of dialogical communication, the ability to actively act at all stages of conflict management. It has been substantiated that the subjectively prosperous staff of educational organisations is able not only to constructively resolve various conflict situations but also to own and be able to form universal, national, civic, family and personal values in the growing youth.
\end{abstract}

Постановка проблеми. Сьогодення висуває нові вимоги до особистісної готовності персоналу освітніх організацій до конструктивного розв'язання конфліктів. Особливо актуальні питання, зумовлені потребою розроблення нових i вдосконалення наявних механізмів управління конфліктами для забезпечення суб'єктивного благополуччя освітян. Освітня діяльність потребує особливих умінь і навичок, необхідних для уникнення, розвитку і розв'язання конфліктних ситуацій, прогнозування результатів власної діяльності, які впливають на всі сфери життя як особистості, так і освітньої організації загалом, ступінь міжособистісних взаємин в інтересах реалізації професійних завдань.

Персонал освітніх організацій відповідно до посадових обов'язків має бути здатним до об'єк- тивного оцінювання конфліктних ситуацій, урегулювання конфліктів, запобігання різноманітним непорозумінням, неузгодженостям. Відповідно актуалізується проблема опанування мистецтва управління конфліктами в усіх сферах життя [3, с. 354], що, безперечно, впливає на якість життя, задоволеність персоналу, самопочуття працівників, їхню поведінку і здатність до самостійних рішень, пошуку виходу зі складних життєвих ситуацій, творчо реалізуючи професійну діяльність та втілюючи «незвичайні ідеї, відхиляючись від традиційних схем мислення, швидко розв'язуючи проблемні життєві ситуації» [8, с. 443-456]. На особливу увагу заслуговує саме суб'єктивне благополуччя персоналу освітніх організацій, що $\epsilon$ показником стану «загального психічного та фізичного комфорту, енергійності, сили та здо- 
рового самопочуття» [24], позитивних емоцій та почуттів, сприяє процвітанню особистості впродовж життя (або навпаки) [27, с. 13].

Водночас, незважаючи на всю актуальність, проблема особистісної готовності персоналу освітніх організацій до конструктивного розв'язання конфліктів як чинника суб'єктивного благополуччя практично залишалася поза увагою дослідників.

Мета статті - дослідити проблему особистісної готовності персоналу освітніх організацій до конструктивного розв'язання конфліктів для досягнення ними суб' єктивного благополуччя.

Виклад основного матеріалу. Нині проблемі розв'язання конфліктів в освітніх організаціях відводиться особливе місце. Варто відзначити, 3 огляду на погляди відомих науковців, що потреба конструктивного розв'язання конфліктів персоналом освітніх організацій є обов'язковим елементом освітньої діяльності $[10 ; 12 ; 14 ; 18 ; 19$ та ін.]. У результаті проведеного аналізу визначень науковців щодо сутності поняття «конфлікт» виявлено велику кількість тлумачень, насамперед завдяки соціальній суперечності. Конфлікт пояснюють через зіткнення протилежних інтересів, думок; загострення певних суперечностей, що зумовлюють ускладнення або гостру боротьбу $[6$, c. 146$]$.

Конфлікт (від лат. conflictus - зіткнення) свідчить про певну завершальну ланку механізму роз'яснень суперечностей у сукупності суспільних відносин. Водночас конфлікт тлумачать по-різному, а саме:

- прихильники психодинамічного підходу пояснюють як постійний елемент людської душі [21];

- мотиваційного підходу - як боротьбу несумісних намірів; послідовність раціональних та конструктивних дій, реалізованих учасниками конфлікту [11, с. 16-25];

- ситуаційного підходу - як реакцію на зовнішню ситуацію [2; 9 та ін.];

- організаційного підходу - як процес і результат дії суперечностей у діяльності організації та підтримуванні конфліктної взаємодії [13; 19];

- особистісного підходу - як прояв конкретних індивідуально-психологічних особливостей у поведінці й діяльності людини під час конфлікту [15];

- системного - як розкриття конфлікту як системи, значної кількості елементів, що взаємодіють [2] тощо.

На особливу увагу заслуговує аналітичний під$x i d$, в основі якого - аналіз структурних складових частин феномену конфлікту, етапів його перебігу [1], навколишнього середовища тощо.

Отже, існують різні підходи, які висвітлюють різні можливості в управлінні конфліктами в організаціях. Більш суперечливої категорії, ніж «кон- флікт», складно знайти. Окрім того, різні погляди щодо вирішення конфлікту вказують на ймовірність появи конфлікту лише за умови відсутності взаємопорозуміння серед людей. Конструктивне розв'язання конфлікту полягає в підвищенні ефективності діяльності персоналу освітньої організації, пошуку різних кутів бачення, значної кількості альтернатив його вирішення тощо для вибору оптимальної стратегії, що поєднує декілька чинників, як-от: тривалість часу розв'язання конфлікту; загальна культура освітян; рівновага між сторонами конфлікту; своєчасність конструктивного розв'язання; наявність медіатора [9; 17].

На особливу увагу заслуговує саме психологічний ракурс взаємодії персоналу освітніх організацій, що становить природний фрагмент людських взаємин. Адже конфлікт неминучий для такої динамічної сфери, як освітня, тому персонал має усвідомлювати його психологічне підгрунтя, володіти практичними навичками врегулювання конфліктних ситуацій.

Готовність персоналу освітніх організацій до розв'язання конфліктів науковці також трактують по-різному, описують як:

- стійку систему професійно важливих якостей працівника, його досвід, знання, навички, уміння конструктивного розв'язання конфлікту [7];

- цілісну якість особистості, що виявляється в іiі емоційно-вольовій мобілізаційності за умови включення в ситуацію конфліктного характеру [16];

- психологічне утворення, зумовлене особливостями професійної поведінки й діяльності в конфліктній ситуації [2] тощо.

Варто зазначити, що для персоналу освітніх організацій готовність до розв'язання конфліктів передбачає опанування вмінь займати конструктивну позицію в освітній діяльності в момент розгортання конфлікту, прагнення дотримуватися настанов і правил діалогічного спілкування, уміння здійснювати всі етапи управління конфліктною ситуацією (уміти діагностувати ймовірність появи конфлікту, прогнозувати особливості його розвитку, запобігати, взаємодіяти в ситуації конфлікту, урегульовувати проблемні ситуаціï) [22].

Вибір стратегії розв'язання конфлікту (суперництва (конкуренції), кооперації, компромісу, уникнення, пристосування) [1; 17] залежить від індивідуальних, сімейних та суспільних переконань, цінностей, досвіду, культури, можливостей та контексту в часі і змінах. Це ті необхідні речі, до яких прагне кожна людина впродовж свого життя, зокрема й персонал освітніх організацій, спираючись на позитивні уявлення, унікальні для кожного, що цілісно формують наші відчуття про нас, хто ми, яких цінностей, принципів варто дотримуватись [26]. Усе разом сприяє досягненню особистістю суб' єктивного благополуччя, впливає 
на безліч чинників, як позитивних, так і негативних, деякі 3 них можуть контролюватися персоналом, а деякі - ні. Серед них варто назвати такі: стійкість та самореалізацію; соціальну емоційну компетентність (емоційний інтелект), особисті реакції на діяльність в освітній організації (виснаження, втому, стрес тощо) в умовах конфліктної ситуації. Особливо це актуально в умовах протидії пандемії коронавірусу COVID-19 і переходу на онлайн-формат роботи та навчання, що потребує психологічної компетентності суб'єктів дистанційного навчання, надання психологічної допомоги у стресових ситуаціях, психологічної підтримки в режимі відеоконференцій тощо.

«Динамічний стан, у якому особистість здатна розвивати свій потенціал, працювати продуктивно та творчо, будувати міцні та позитивні стосунки 3 іншими людьми та сприяти їхньому розвитку» [23, с. 15], сприятиме розвитку в персоналу освітніх організацій готовності до конструктивного розв'язання конфліктів. Саме здатність персоналу освітніх організацій контролювати із плином часу цілу низку чинників, як конструктивних, так і небажаних, може унеможливити вплив на емоційний, фізичний та когнітивний стан у відповідь [25], забезпечити досягнення їхнього суб'єктивного благополуччя. Це, у свою чергу, потребує усвідомлення персоналом освітніх організацій різноманіття ресурсів, доступних для подолання психоемоційного напруження, виснаження й конфліктності загалом. Серед таких ресурсів варто відзначити:

- фізичні (фізичний розвиток, спосіб життя, здорове харчування тощо);

- ментальні (знання, уміння, навички, досвід, осмисленість життєвої позиції, цілі, пріоритети тощо);

- професійні (відповідність професійній орієнтації, рівень професійної мотивації, схильності тощо);

- естетичні (уміння насолоджуватись прекрасним - музикою, художнім мистецтвом, творчим розвитком особистості, творче мислення тощо);

- соціальні (навички спілкування, здатність до взаєморозуміння, надання і прийняття допомоги, здатність до реалізації колективної діяльності, виконання ролей чи функцій тощо);

- емоційні (емоційний інтелект, розуміння й керування почуттями, як власними, так і інших людей, опанування навичок саморегуляції й екологічної свободи прояву почуттів);

- духовні (віра в силу духу, духовні практики, релігія, смисложиттєві орієнтації, духовно-моральні цінності та принципи, життєва позиція тощо).

Отже, у разі активізації особистісних ресурсів персонал освітніх організацій здатний сприяти зміцненню власного фізичного і психологічного благополуччя й адаптивності шляхом сприяння забезпеченню i підтримці необхідного рівня ресурсів для якісного виконання професійних обов'язків та збереження повноцінного функціонування освітньої організації. Цьому сприяють психопрофілактична робота, спрямована на розвиток саморегуляції, стресостійкості, конфліктогенної компетентності, здатності протидіяти конфліктам і конфліктним ситуаціям через активізацію внутрішніх і зовнішніх ресурсів, що дозволить досягнути суб'єктивного благополуччя, що передбачає стан загального психічного та фізичного комфорту, енергійності, сили та здорового самопочуття [24], дозволяє поєднувати позитивні емоції, а також сприє процвітанню особистості протягом життєвого шляху (або навпаки) [27, с. 13].

У контексті досліджуваної проблеми важливим є розуміння суб'єктивного благополуччя як «широкої категорії феноменів, що свідчить про емоційні реакції людей, їх задоволеність окремими сферами життя, а також їх судження про якість життя загалом» [24]. Як зазначає Е. Дінер, суб'єктивне благополуччя поєднує в собі різні складові частини задоволеності життям, а саме: когнітивну, що свідчить про рефлексивні судження персоналу освітніх організацій, позитивний перебіг їхньої професійної діяльності; емоційну баланс між позитивними і негативними емоціями, які супроводжують персонал упродовж певного періоду часу (афективний складник), складові частини, суб'єктивне благополуччя. Структура суб'єктивного благополуччя містить три основні компоненти: задоволеність, приємні та неприємні емоції, які разом формують рівень суб' єктивного благополуччя [24, с. 71-75], а благополучні люди краще працюють і мають більше бажання працювати. Окрім того, високий рівень суб'єктивного благополуччя сприяє емоційній стійкості, відсутності негативних переживань та заклопотаності, зумовлює ентузіазм, любов до себе, самоконтроль, переживання позитивного ставлення до інших і світу загалом, переважання позитивного мислення щодо власного минулого, теперішнього і майбутнього тощо [28].

У результаті вивчення суб' єктивного переживання благополуччя (неблагополуччя) персоналу освітніх організацій, проведеного аналізу різних підходів науковців до його тлумачення можна дійти висновку, що це інтегративний феномен, який залежить від різних чинників 3 усіх сторін буття персоналу, включає значну сукупність особливостей ставлення, настанов стосовно довкілля, власної організації, кожного працівника (зокрема, базові переконання стосовно світу, інших працівників, себе), їхніх цінностей, принципів, стерео- 
типів, уявлень, норм, приписів і правил професійної діяльності тощо.

Варто також зазначити, що задоволеність i благополуччя є досить значущими для персоналу освітніх організацій і посідають центральне місце в їхній самосвідомості, а також у всьому суб'єктивному (внутрішньому) світі персоналу, будуються на суб' єктивному емоційно забарвленому ставленні до змістовних подій освітньої організації, явищ, сприяють досягненню внутрішнього комфорту, духовної урівноваженості, задоволеності якістю життя (професійне й особисте), переживання благополуччя i щастя загалом. Зрозуміло, що це впливає на переживання позитивних чи негативних емоцій. Чим більше позитиву переживає персонал освітніх організацій, тим більша його задоволеність як особистим, так і професійним життям. Це впливає на рівень суб'єктивного благополуччя, що містить не лише емоційну оцінку, а й уявлення щодо власного благополуччя (благополуччя інших людей) чи неблагополуччя (когнітивні судження), ураховує об'єктивні критерії благополуччя, успішність персоналу, показники здоров'я працівників освітніх організацій, матеріальний достаток тощо. У сукупності все разом формує загальну оцінку якості життя персоналу відповідно до обраних освітньою організацією критеріїв. Окрім того, це впливає і на здатність персоналу вирішувати різні професійні завдання, проблеми в колективі, бути готовим до врегулювання конфліктних ситуацій, формування позитивного психологічного клімату тощо.

Адже лише суб'єктивно благополучний персонал освітніх організацій здатний не лише конструктивно врегульовувати різні конфліктні ситуації, а й формувати в молоді загальнолюдські (життя, людина, добро, соціум, щастя, справедливість тощо), національні (національна ідея, рідна мова, традиції, звичаї, мова інших народів, національна символіка, фольклор тощо), громадянські (демократичні права й обов'язки, толерантність до інакомислячих, повага до культури і традицій інших національностей, релігійна терпимість тощо), сімейні (цінності родинного життя: повага, любов, взаємодопомога, гармонія тощо) i особистісні (самореалізація, здоров'я, освіченість тощо) цінності [20, с. 259-266].

Досягненню суб'єктивного благополуччя персоналу освітніх організацій сприятиме задоволеність соціальним статусом, актуальним станом спільноти працівників і причетності до неї, взаємозв'язками в колективі, що свідчить про соиіальне благополуччя персоналу. Особливості духовної культури персоналу освітніх організацій, їхні ціннісні орієнтації, усвідомленість і переживання сенсу власного життя - духовне благополуччя. Щодо гарного фізичного самопочуття, тілесного комфорту кожного працівника, їхнього фізичного статусу, то це висвітлюватиме фізичне благополуччя. Значну роль у досягненні суб'єктивного благополуччя відіграє i задоволеність матеріальним аспектом свого існування, його стабільністю - матеріальне благополуччя. Окрім того, узгодженість психічних процесів і функцій, відчуття внутрішньої рівноваги і гармонії свідчитиме про психологічне благополуччя тощо. Усі названі елементи складають загальну картину суб'єктивного благополуччя i, звісно, взаємопов'язані i взаємодіють один $з$ одним. Суб'єктивне благополуччя персоналу освітніх організацій впливає як на здатність реалізації професійної діяльності, так і на готовність до конструктивного розв'язання конфліктів в освітній сфері, проявляється в:

- регламентації самопочуття, внутрішньому ставленні персоналу до взаємодії із зовнішнім світом, самоприйнятті в соціумі, формуванні ідентичності працівників, їхній поведінці в конфліктних ситуаціях (регулятивна функція);

- сприянні адаптації, інтеграції, моделюванню, структуруванню в індивідуальному когнітивному просторі персоналу у процесі розв' язання конфліктів (функція управління когнітивними процесами);

- забезпеченні творчого руху на шляху до реалізації цілей організації, здібностей кожного працівника освітньої організації у врегулюванні конфліктних ситуацій (функція розвитку);

- сприянні забезпеченню вибору стратегій конструктивної поведінки у процесі розв'язання конфліктів залежно від локусу благополуччя і спрямованості особистості (поведінкова функція).

Висновки. Отже, особистісна готовність персоналу освітніх організацій до конструктивного розв'язання конфліктів $\epsilon$ важливим чинником суб'єктивного благополуччя, що передбачає опанування вмінь займати конструктивну позицію в освітній діяльності в момент розгортання конфлікту, прагнення дотримуватися настанов і правил діалогічного спілкування, уміння активно діяти на всіх етапах управління конфліктною ситуацією. Вибір стратегії розв'язання конфлікту залежить від індивідуальних, сімейних та суспільних переконань, цінностей, досвіду, культури, можливостей та контексту в часі і змінах, до яких прагне кожна людина впродовж свого життя. Саме здатність персоналу освітніх організацій контролювати із плином часу цілу низку чинників, як конструктивних, так і небажаних, може запобігти впливу на емоційний, фізичний та когнітивний стан у відповідь, забезпечувати досягнення ними суб'єктивного благополуччя.

Перспективи подальших досліджень. Перспективами вбачаємо необхідність розроблення 
програми сприяння формуванню особистісної готовності персоналу освітніх організацій до кон- структивного розв'язання конфліктів для досягнення ними суб' єктивного благополуччя.

\section{ЛІТЕРАТУРА}

1. Андреева Г.М. Социальная психология : учебник для студентов вузов. Москва : Аспект-Пресс, 2000. $373 \mathrm{c}$.

2. Анцупов А.Я., Шипилов А.И. Конфликтология : учебник для вузов. Москва : Эксмо, 2009. 512 с.

3. Балахтар В.В. Педагогіка і психологія в соціальній роботі : навчально-методичний посібник для студентів вищих навчальних закладів. Київ : Талком, 2017. 444 с.

4. Балахтар К.С. Значення керівництва та лідерства в управлінні. Регіональний вимір сенситивності механізмів управління: правовий, фінансово-економічний, психологічний аспекти : матеріали VII Всеукраїнської науково-практичної конференції, 10-11 грудня, 2009 р. Чернівці : Букрек, 2010. C. 340-346.

5. Балахтар K.C. Well-being as a factor of successful teacher activity. Соціальна робота і проблеми міграційних проиесів у глобалізованому світі : матеріали Міжнародної науково-практичної конференції, м. Чернівці, 3-4 травня 2018 р. Чернівці : Чернівецький нац. ун-т, 2018. С. 19-23.

6. Бандурка О.М., Скакун О.Ф. Юридична деонтологія : підручник. Харків : Вид-во НУВС, 2002. 336 с.

7. Варлакова С.О. Формування готовності майбутніх практичних психологів до розв'язання міжособистісних конфліктів : автореф. дис. ... канд. психол. наук. Київ, 2011. 21 с.

8. Гилфорд Дж. Три стороны интеллекта / пер. с англ. Э.А. Голубева. Психология мышиления. Москва : Прогресс, 1965. С. 443-456; 162-164.

9. Гришина Н.В. Психология конфликта. Санкт-Петербург : Питер, 2008. 544 с.

10. Дзюба Т.М. Комплекс методик для діагностики психологічної готовності керівника школи до взаємодії в умовах конфлікту / за наук. ред. Л.М. Карамушки. Полтава : ПОІППО. 2005. 64 с.

11. Дойч М. Разрешение конфликтов. Конструктивные и деструктивные процессы : социальнополитический журнал. 1997. № 1. С. 16-25.

12. Долгий О.А., Чехович Л.М. Особливості управління конфліктами у колективі освітньої установи. Державне управління: удосконалення та розвиток. 2019. № 9. DOI: 10.32702/2307-2156-2019.9.1.

13. Ершов А.А. Как избежать конфликта. Ленинград : Изд-во ЛГУ, 1980. 174 с.

14. Карамушка Л.М. Управління конфліктами в освітніх організаціях. Київ : Шкільний світ, 2011. 128 с.

15. Крогиус Н.В. Познание людьми друг друга в конфликтной деятельности : автореф. дис. ... д-окт. психол. наук. Саратов, 1979. 40 с.

16. Лазарєва В.В. Формуванняготовності майбутніх дільничних інспекторів MBC дорозв' язання конфліктних ситуацій у процесі фахової підготовки : автореф. дис. ... канд. пед. наук. Тернопіль, 2013. 20 с.

17. Ложкин Г.В., Повякель Н.И. Практическая психология конфликта : учебное пособие. Киев : МАУП, 2002. $256 \mathrm{c}$.

18. Матійків І.М. Роль конфліктологічної компетентності керівника у створенні безпечних психологічних умов праці у педагогічному колективі. Науковий вісник Львівського державного університету внутрішніх справ. 2012. Вип. 2 (1). С. 434-443

19. Пірен М.І. Конфліктологія : підручник. Київ : МАУП, 2007. 360 с.

20. Ткачова Н.О. До питання формування ціннісних орієнтацій у студентів вищих навчальних закладів. Вісник Львівського університету. 2006. Вип. 21. С. 259-266.

21. Фрейд 3. Введение в психоанализ : лекции / авторы очерка о Фрейде Ф.В. Бассин и М.Г. Ярошевский. Москва : Наука, 1989. 459 с.

22. Холковська І.Л. Принцип управління-самоуправління у формуванні готовності майбутніх учителів до попередження і розв'язання конфліктів. Проблеми підготовки сучасного вчителя. 2013. № 8. Ч. 2. C. 201-206.

23. Day C., Qing G. Teacher emotions: Wellbeing and effectiveness. Advances in Teacher Emotion Research / P.A. Schutz, M. Zembylas (eds). New York : Springer, 2009. P. 15-31.

24. Diener E. The science of well-being: The collected works of Ed Diener. New York : Springer, 2009.

25. Gillett-Swan J.K., Sargeant J. Wellbeing as a process of accrual: Beyond subjectivity and beyond the moment. Social Indicators Research, 2014.

26. McCallum F., Price D. Nurturing wellbeing development in education. New York : Routledge, 2016. P. 17.

27. Seligman M.E.P. Flourish: A visionary new understanding of happiness and wellbeing. New York : Free Press, 2011.

28. Seligman M.E.P., Rashid T., Parks A.C. Positive psychotherapy. American Psychologist. 2006. № 61. P. 774-788. 


\section{REFERENCES}

1. Andreeva H.M. (2000). Sotsyalnaia psykholohyia [Social psychology]: ucheb. dlia studentov vuzov. Moskva: Aspekt-Press [in Russian].

2. Antsupov A.Ya. \& Shypylov A.Y. (2009). Konflyktolohyia [Conflictology]: uchebnyk dlia vuzov. Moskva : EKSMO [in Russian].

3. Balakhtar V.V. (2017). Pedahohika i psykholohiia v sotsialnii roboti [Pedagogy and psychology in social work]: navchalno-metodychnyi posibnyk dlia stud. vyshch. navch. zakladiv. Kyiv : Talkom [in Ukrainian].

4. Balakhtar K. (2010). Znachennia kerivnytstva ta liderstva $v$ upravlinni [The importance of leadership and leadership in management]. Rehionalnyi vymir sensytyvnosti mekhanizmiv upravlinnia: pravovyi, finansovo-ekonomichnyi, psykholohichnyi aspekty: materialy VII Vseukrainskoi nauk.-prakt. konf. (10-11 hrudnia, 2009 r.), 340-346. Chernivtsi : Bukrek [in Ukrainian].

5. Balakhtar K. (2018). Well-beinh as a factor of suctsessful teacher activity. Materialy Mizhnarodnoi naukovo-praktychnoi konferentsii "Sotsialna robota i problemy mihratsiinykh protsesiv u hlobalizovanomu sviti" (Chernivtsi, 3-4 travnia 2018 roku), 19-23. Chernivtsi : Chernivetskyi nats. un-t [in English].

6. Bandurka O.M. \& Skakun O.F. (2002). Yurydychna deontolohiia [Legal deontology] : pidruchnyk. Kharkiv : Vyd-vo NUVS [in Ukrainian].

7. Varlakova Ye.O. (2011). Formuvannia hotovnosti maibutnikh praktychnykh psykholohiv do rozviazannia mizhosobystisnykh konfliktiv [Formation of readiness of future practical psychologists to resolve interpersonal conflicts]: avtoref. dys. ... kand. psykhol. nauk. Kyiv [in Ukrainian].

8. Hylford, Dzh. (1965). Try storony yntellekta [Three sides of intelligence]. Holubeva, Э.A. (per. s anhl) Psykholohyia myshlenyia, 443-456, 162-164. Moskva : Prohress [in Russian].

9. Hryshyna N.V. (2008). Psykholohyia konflykta [Psychology of conflict]. Sankt-Peterburh : Pyter [in Russian].

10. Dziuba T.M. (2005). Kompleks metodyk dlia diahnostyky psykholohichnoi hotovnosti kerivnyka shkoly do vzaiemodii v umovakh konfliktu [A set of methods for diagnosing the psychological readiness of the school principal to interact in a conflict] ; za nauk. red. L.M. Karamushky. Poltava: POIPPO [in Ukrainian].

11. Doich M. (1997). Razreshenye konflyktov. Konstruktyvnye y destruktyvnye protsessy [Conflict resolution. Constructive and destructive processes]. Sotsyalno-polytycheskyi zhurnal. 1, 16-25 [in Russian].

12. Dolhyi O.A. \& Chekhovych L.M. (2019). Osoblyvosti upravlinnia konfliktamy u kolektyvi osvitnoi ustanovy [Features of conflict management in the staff of the educational institution]. Derzhavne upravlinnia: udoskonalennia ta rozvytok. 9. URL: http://www.dy.nayka.com.ua/?op=1\&z=1483. DOI: 10.32702/2307-2156-2019.9.1 [in Ukrainian].

13. Ershov A.A. (1980). Kak yzbezhat konflykta [How to avoid conflict]. Lenynhrad : Yzd-vo LHU [in Russian].

14. Karamushka L.M. (2011). Upravlinnia konfliktamy v osvitnikh orhanizatsiiakh [Conflict management in educational organizations.]. Kyiv : Shkilnyi svit [in Ukrainian].

15. Krohyus N.V. (1979). Poznanye liudmy druh druha v konflyktnoi deiatelnosty [People's cognition of each other in conflict activities]: avtoref. dys. ... d-ra psykhol. nauk. Saratov [in Russian].

16. Lazarieva V.V. (2013). Formuvannia hotovnosti maibutnikh dilnychnykh inspektoriv MVS do rozviazannia konfliktnykh sytuatsii u protsesi fakhovoi pidhotovky [Formation of readiness of future district inspectors of the Ministry of Internal Affairs to resolve conflict situations in the process of professional training]: avtoref. dys. ... kand. ped. nauk. Ternopil [in Ukrainian].

17. Lozhkyn H.V. \& Poviakel N.Y. (2002). Praktycheskaia psykholohyia konflykta [Practical psychology of conflict]: ucheb. posobye. Kyev : MAUP [in Russian].

18. Matiikiv I. (2012). Rol konfliktolohichnoi kompetentnosti kerivnyka u stvorenni bezpechnykh psykholohichnykh umov pratsi u pedahohichnomu kolektyvi [The role of conflictological competence of the head in creating safe psychological working conditions in the teaching staff]. Naukovyi visnyk Lvivskoho derzhavnoho universytetu vnutrishnikh sprav. Seriia psykholohichna : zb. nauk. pr. Lviv : LvDUVS, 2(1), 434-443 [in Ukranian].

19. Piren M.I. (2007). Konfliktolohiia [Conflictology]: pidruchnyk. Kyev : MAUP [in Ukranian].

20. Tkachova N. (2006). Do pytannia formuvannia tsinnisnykh oriientatsii u studentiv vyshchykh navchalnykh zakladiv [On the formation of value orientations in students of higher educational institutions]. Visnyk Lvivskoho universytetu: zb. nauk. pr. LNU, 21, 259-266 [in Ukranian].

21. Freid Z. (1989). Vvedenye v psykhoanaliz [Introduction to psychoanalysis]: Lektsyy. Avtory ocherka o Freide F.V. Bassyn y M.H. Yaroshevskyi. Moskva : Nauka [in Russian].

22. Kholkovska I. (2013). Pryntsyp upravlinnia-samoupravlinnia u formuvanni hotovnosti maibutnikh uchyteliv do poperedzhennia i rozviazannia konfliktiv [The principle of management-self-management in the for- 
mation of the readiness of future teachers to prevent and resolve conflicts]. Problemy pidhotovky suchasnoho vchytelia, 8 (ch. 2), 201-206 [in Ukranian].

23. Day, C., \& Qinh, H. (2009). Teacher emotions: Wellbeing and effectiveness. In P.A. Schutz \& M. Zembylas (eds), Advantses in Teacher Emotion Research. Sprinher, 15-31.

24. Diener, E. (2009). The science of well-being: The collected works of Ed Diener. New York, NY : Springer.

25. Gillett-Swan J.K., Sargeant J. (2014). Wellbeing as a process of accrual: Beyond subjectivity and beyond the moment. Social Indicators Research.

26. McCallum, F., \& Price, D. (2016). Nurturing wellbeing development in education. Routledge, NY, 17.

27. Seligman M.E.P. (2011). Flourish: A visionary new understanding of happiness and wellbeing. New York : Free Press.

28. Seligman M.E.P., Rashid, T. \& Parks, A.C. (2006). Positive psychotherapy. American Psychologist, 61, 774-788. 